\title{
Meiotic expression of modified chromosome constitution and structure in $\times$ Triticosecale Wittmack
}

\author{
Consuelo Soler, \\ Pilar Garcia† and \\ Nicolás Jouve $\ddagger$
}

\author{
* Unidad Banco Nacional de Germoplasma, Instituto \\ Nacional de Investigaciones Agrarias, La Canaleja, \\ Alcalá de Henares, Madrid, Spain. \\ $\dagger$ Servicio de Investigacion Agraria, Comunidad de \\ Madrid, El Encín, Madrid, Spain. \\ † Departamento de Biología Celular y Genética, \\ Universidad de Alcalá de Henares, Madrid, Spain.
}

The chromosome constitution and the meiotic behaviour of plants in the F3, F4 and F6 progenies of one cross between 6x-triticale (female) and Triticum aestivum (male) were analysed. C-banding of meiosis proved to be a good method to score the individual levels of pairing, to verify the chromosome constitution, and to detect structural variations. Amongst the plants examined, the chromosome constitution varied in the third genome (0-7" $D$ and $0-6$ " $R$ ), and all plants had the whole $A$ and $B$ genomes in common. Rye chromosomes presented some modifications in distribution of heterochromatin. Other karyological variations such as $D / R$ centric fusions or telocentrics were also occasionally observed. Segregation for missing heterochromatin in the telomeres of the arm 3RS was found amongst the plants. Chromosome pair 3R showed significantly more chiasmata in plants in which heterochromatin is deleted ( --$)$ or present $(++)$ in both telomeres than in heterozygous $(-+)$. Both heterochromatin and chromosome constitution are discussed in relation to factors affecting meiotic pairing and interest in setting out new hybridizations.

\section{INTRODUCTION}

After introduction of Giemsa staining for differential chromosome analysis in triticale it became evident that heterochromatin is located at the telomeres of 11 out of the 14 chromosome arms of the rye chromosomes, and at the centromeres and interstitial regions of the wheat chromosomes.

The telomeric heterochromatin of rye chromosomes has been correlated with certain morphological and cytological undesirable characters. Kaltsikes et al. (1975) noticed that the presence of rye heterochromatin in triticale causes aberrant nuclei in a coenocytic endosperm. The production of such aberrant nuclei leads to the formation of cavities in the endosperm and shrivelling grain at maturity.

The capacity of C-heterochromatin to affect univalency and aneuploidy in triticale has been discussed previously (Roupakias and Kaltsikes, 1977; reviews of Gupta and Priyadarshan, 1982, and Lukaszewski and Gustafson, 1986). Accordingly, a series of studies have been carried out to analyse the chromosome constitution and the amount of telomeric heterochromatin of rye chromosomes in secondary triticale lines (Lukaszewski and Apolinarska, 1981; Ziauddin and Kasha, 1982; Varghese and Lelley, 1983; Gustafson et al., 1985; Lukaszewski, 1986).

Giemsa banding could be very informative to investigate the influence of structural and/or numerical differences of chromosomes on the meiotic pairing in genetically well defined lines of triticale. In this paper, we applied this technique to study the influence of both chromosome constitution and telomeric C-heterochromatin on the meiotic association of chromosomes, using a sample of karyotypically unstabilized plants belonging to the early progenies of a cross between a primary $6 x$-triticale line and a common wheat. The pairing affinity of wheat chromosomes in comparison with rye chromosomes in triticale is also discussed.

\section{MATERIALS AND METHODS}

The plant material studied derived from the cross between the triticale line "P-60" and the common wheat cultivar "Chaimite". "P-60" is a hexaploid primary line which was obtained at the Department of Cereals and Legumes by one of the coauthors (C. Soler) at I.N.I.A. This line showed homogeneity for many biochemical and morpho- 
logical characters after application of different electrophoretical and agronomic analyses. "Chaimite" is a Portuguese wheat variety commonly used in wheat improvement in Spain.

Seven F3, seventeen F4 and twenty-four F6 plants were utilized in this study. The plants were selected at random within the progenies of each generation of self-pollination. This plant material formed a part of an ongoing program designed to obtain secondary triticale lines.

Karyological analysis was carried out in all plants analysed. The criteria defined in the Workshop on Wheat Chromosome Nomenclature held during the 7th International Wheat Genetic Symposium (Cambridge, 1988) were adopted to identify and designate the wheat chromosomes. The amount and distribution of heterochromatin and the size and external morphology for the rye chromosomes were used as identifying features, using the $\mathrm{C}$-banding patterns for the somatic chromosomes according to the International Workshop on Rye Chromosome Nomenclature and Homoeology Relationships (Sybenga, 1983).
To identify individual wheat chromosomes at first metaphase in meiosis, the pattern of $\mathrm{C}$ banding for nine chromosomes (4A, 7A and the seven of the B genome) described earlier (Ferrer et al., 1984) was used. In addition, wheat chromosomes $2 \mathrm{~A}, 5 \mathrm{~A}$ and $6 \mathrm{~A}$ were recognized using the somatic heterochromatin descriptions as a reference.

Seminal roots of about $\frac{1}{2} \mathrm{~cm}$ in length were excised, pretreated in cool water for 28 hours and fixed in 45 per cent acetic acid for 24 hours. Anthers for meiotic analysis of pollen mother cells (PMCs) were fixed in acetic acid-alcohol 1:3. Preparations and staining of both somatic and meiotic chromosomes were carried out by the Giemsa C-binding technique as described earlier (Jouve et al., 1980).

\section{RESULTS}

\section{Chromosome constitution and modifications}

The chromosome constitutions of the segregant plants (F3 to F6) were studied (table 1). The plants

Table 1 Variation of somatic chromosome constitution of the plant material analyzed. "= chromosome pair; '= monosomic; $t=$ telosomic; $d=$ telomeric duplication;,+++- and $--=$ homozygous normal, heterozygous and homozygous deficient bivalent for a telomeric deletion in $3 \mathrm{RS}$, respectively; ${ }^{*}=$ plants with $2 n=42$ and similar chromosome constitutions used to analyse the influence of telomeric heterochromatin of $3 R S$ on pairing; $7 R L .2 D S=$ centric fusion

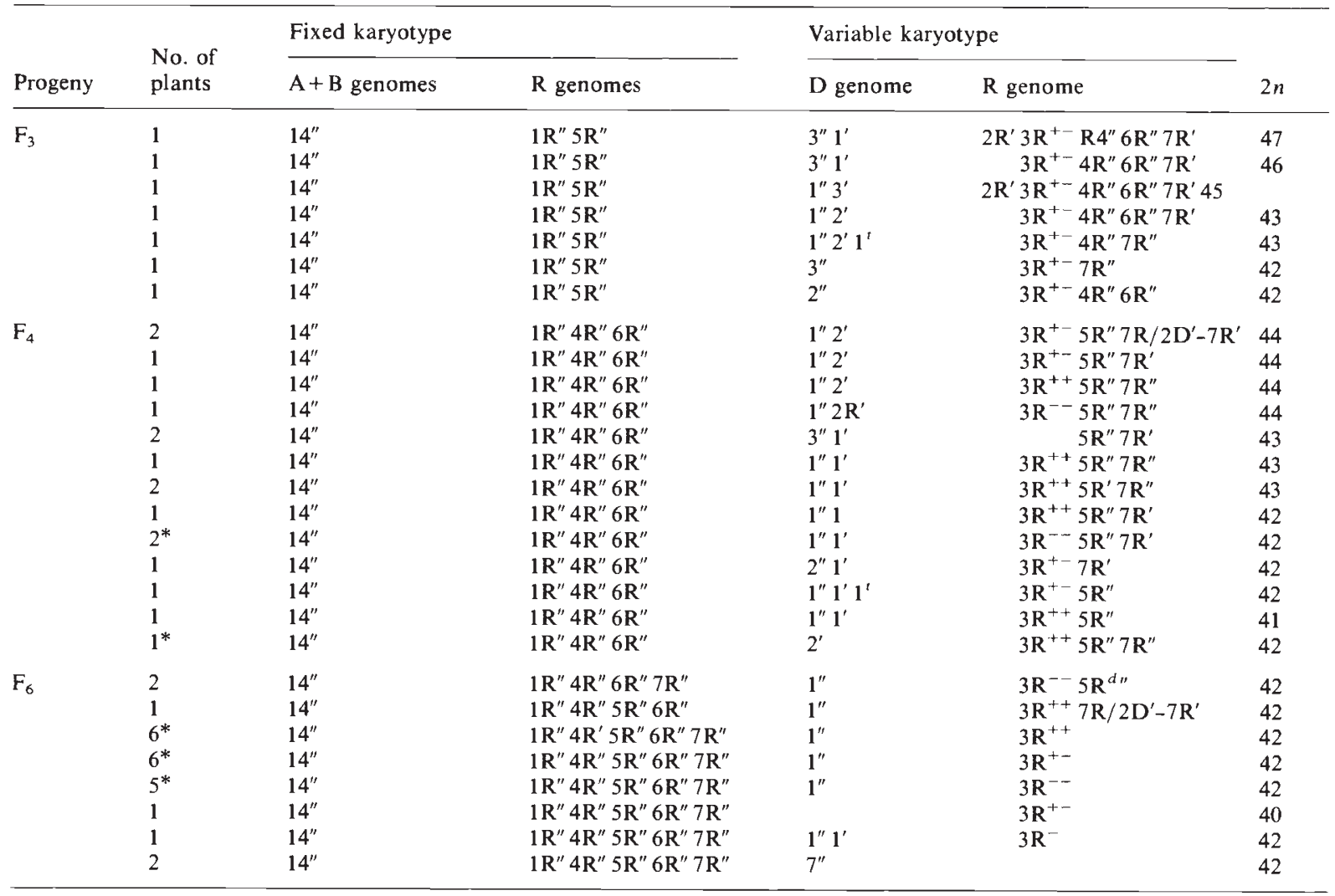


showed a uniform karyotype for the $A$ and $B$ genomes ( 7 " $\left.\mathrm{AA}+7^{\prime \prime} \mathrm{BB}\right)$ and a unstabilized constitution for the third genome $(0-17 \mathrm{D}$ and $0-13 \mathrm{R})$. The total chromosome number (40 to 47 ) and the range of variable karyotypes showed a tendency to regularize over generation time. Only two out of the 48 plants analysed showed the common wheat chromosome constitution, incorporating the seven chromosomes of the D genome instead of the rye chromosomes. Chromosome $2 \mathrm{R}$ was absent in all plants analysed, with the exception of two plants in the F3 in which it was present as a monosomic addition. The chromosomes $3 R, 4 R$, $5 R, 6 R$ and $7 R$ were sometimes either absent or present in monosomic condition. On the average, 18.3 and 80.4 per cent, respectively, for the $D$ and $R$ genomes, were fixed in disomic condition in 44 out of the 46 karyotyped triticale plants.

Two plants showed heterozygosity for a pair composed by the chromosome $7 \mathrm{R}$ and the centric fusion product 7RL.2DS, and two plants showed the arm 2DL as a mono-telocentric addition. This was probably produced by misdivision in meiosis during an earlier generation. The presence of chromosome 2D in many plants lacking in chromosome $2 \mathrm{R}$ was confirmed by $\mathrm{C}$-banding.

Modifications affecting both C-banding pattern and size of the telomeric heterochromatin in rye chromosomes were found amongst the segregant plants (fig. 1). The modifications consisted of duplication, reduction or loss of heterochromatin. Thus, chromosomes $1 \mathrm{R}, 3 \mathrm{R}, 4 \mathrm{R}, 5 \mathrm{R}$, and $7 \mathrm{R}$ were found as more or less modified chromosomes in some plants as compared to the $\mathrm{R}$ chromosomes of the parental triticale "P-60". Missing heterochromatin in the telomeres of the short arm of chromosome $3 \mathrm{R}$ was the most evident modification and emerged segregating among the plants on each successive generation. Plants were classified as homozygous deficient when heterochromatin was deleted from both telomeres of 3RS (--), heterozygous (+-) and homozygous normal in which $3 \mathrm{RS}$ exhibited in both telomeres a C-heterochromatin band $(++)$. The telomeric heterochromatin on the arm 4RL occasionally appeared as a deletion. A duplication of the telomeric heterochromatin of arm 5RL was observed in some plants.

\section{Meiotic pairing behaviour}

The meiotic pairing was individually analysed per each identified chromosome at first meiotic metaphase (fig. 2). Data on chiasma frequencies per chromosome arm and genomes are registered for
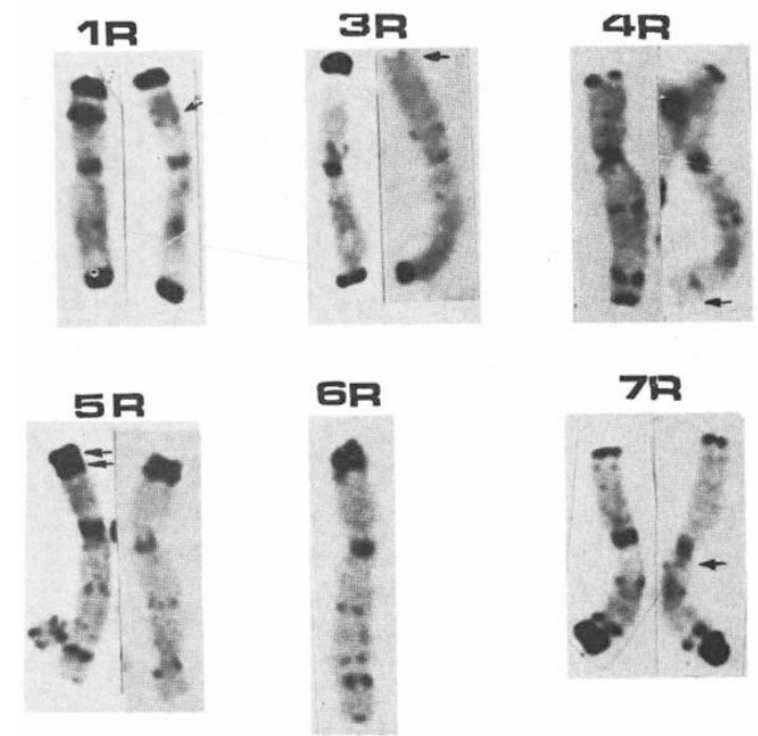

Figure 1 Magnification of rye chromosomes in segregant plants showing some modifications in heterochromatic blocks (arrows).

the plants grouped according to their generation (table 2).

It was observed that; (i) the maximum chromosome association coincided successfully with expectations of $14 \mathrm{AA}+\mathrm{BB}$ bivalents plus a variable number of bivalents, equal to $D+R$ pairs, in each plant; (ii) the wheat chromosome pairs showed a higher mean number of chiasmata per bivalent $(1 \cdot 61-2 \cdot 13)$ than the rye ones $(0 \cdot 85-1 \cdot 47)$, regardless of the chromosome constitution; (iii) a certain variation for both wheat and rye pairing values was observed amongst the plants. However, the total mean number of chiasmata in rye and wheat bivalents per plant followed similar tendencies and a relatively close correlation between chiasma frequency of wheat and rye chromosomes was observed $(r=0.7138 ; t=6.0305 ; \mathrm{df}=44 ; P<$ 0.001 ) amongst the plants (fig. 3); (iv) long arms paired more than short arms regardless their chromosome nature; and (v) rye-wheat bivalents (2DS.7RL-7R) and trivalents (2D-2DS.7RL-7R) with unambiguous chiasmatic associations and cooriented centromeres were observed in two plants carrying the 7RL.2DS centric fusion.

The influence of telomeric heterochromatin of the short arm of chromosome $3 \mathrm{R}$ on the meiotic pairing was comparatively analyzed. Plants having $2 n=42$ and similar chromosome constitution (marked with asteriks in table 1) were grouped according to the telomeric structure of chromosome $3 \mathrm{R}$. Chromosome pair $3 \mathrm{R}$ showed moder- 

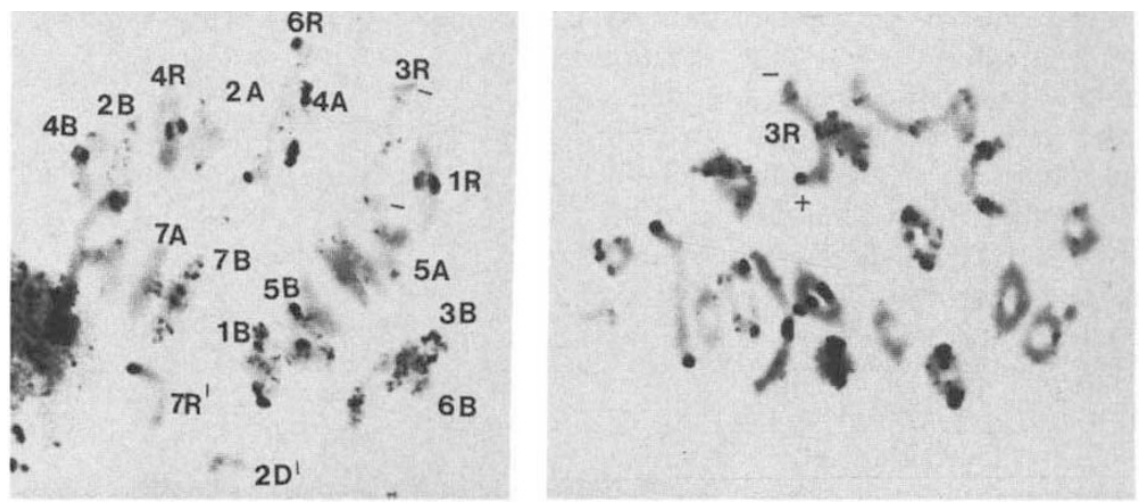

Figure 2 Micrographs on chromosome pairing in different plants from segregating progenies: (a) $2 n=41\left(3 \mathrm{R}^{--}\right)$, and (b) $2 n=44$ $\left(3 \mathrm{R}^{+-}\right)$.

ately more chiasmata in short arm in homozygous normal $(++)$ than in homozygous deficient $(--)$ bivalents. However, when comparisons of the mean number of chiasmata in $3 \mathrm{RS}--$ and $3 \mathrm{RS}++$ among the different groups of plants were performed by $t$-tests the deviations were not significant (table 3).

A significant reduction in pairing level was noted in heterozygous deficient $3 \mathrm{R}+-$ bivalents, regardless of the chromosome number and structure of each plant. The chromosome pair $3 R$ formed more univalents or open rod bivalents in the short arm in heterozygous than in both homozygous normal and homozygous deficient plants.

\section{DISCUSSION}

The variation in chromosome composition of the third genome in plants of F3 and following generations of the cross between $6 x$-triticale and $T$. aestivum could be conditioned by chromosome constitution of the F2 plant from which they were

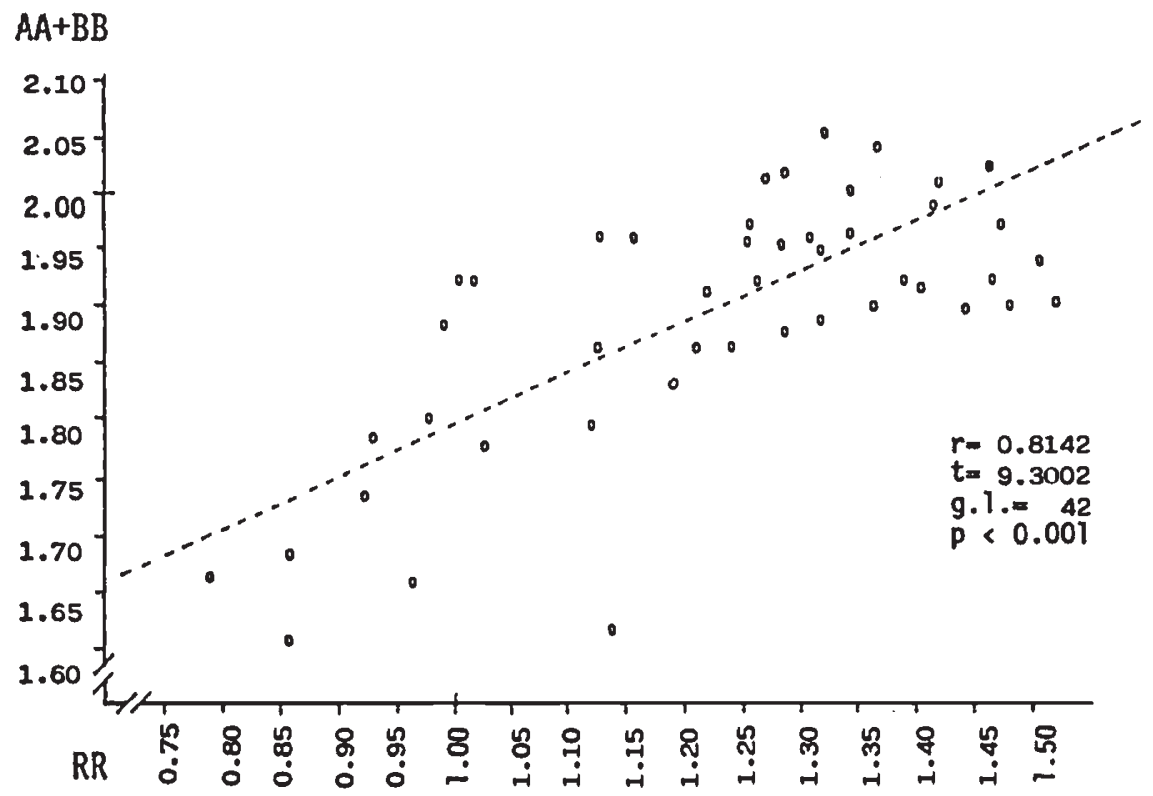

Figure 3 Relationship between mean chiasmata number in wheat and rye chromosomes of 44 segregant plants analysed. 
Table 2 The mean number of chiasmata per chromosome arm ( $2 \mathrm{AS}$ to $7 \mathrm{RL}$ ) and per bivalent in the A-, B- and R-genome chromosomes, of the F3, F5 and F6 plants analyzed. Contingency $\chi^{2}$ tests concern the relative contribution to the meiotic configurations (univalents, rod bivalents and ring bivalents) of each chromosome pair among the plants in each generation. ${ }^{*}=$ Significant at the level of 5 per cent

\begin{tabular}{|c|c|c|c|}
\hline & $\mathrm{F}_{3}$ & $\mathrm{~F}_{4}$ & $F_{6}$ \\
\hline $2 \mathrm{AS}$ & 0.77 & 0.79 & 0.87 \\
\hline $2 \mathrm{AL}$ & $1 \cdot 13$ & $1 \cdot 22$ & $1 \cdot 30$ \\
\hline $4 \mathrm{AS}$ & 0.59 & 0.67 & 0.65 \\
\hline $4 \mathrm{AL}$ & 0.98 & 1.07 & 1.08 \\
\hline $5 \mathrm{AS}$ & 0.78 & 0.73 & 0.71 \\
\hline $5 \mathrm{AL}$ & $1 \cdot 16$ & $1 \cdot 17$ & $1 \cdot 20$ \\
\hline $6 \mathrm{AS}$ & 0.76 & 0.79 & 0.82 \\
\hline $6 \mathrm{AL}$ & 1.05 & $1 \cdot 13$ & $1 \cdot 22$ \\
\hline $7 \mathrm{AS}$ & 1.00 & 0.96 & 1.05 \\
\hline $7 \mathrm{AL}$ & $1 \cdot 12$ & 1.06 & $1 \cdot 14$ \\
\hline 1BS & 0.67 & 0.64 & 0.68 \\
\hline $1 \mathrm{BL}$ & $1 \cdot 17$ & $1 \cdot 15$ & $1 \cdot 10$ \\
\hline 2BS & 0.93 & 0.96 & 1.05 \\
\hline $2 \mathrm{BL}$ & 1.06 & $1 \cdot 12$ & $1 \cdot 12$ \\
\hline 3BS & 0.77 & 0.79 & 0.87 \\
\hline $3 B L$ & $1 \cdot 14$ & $1 \cdot 12$ & $1 \cdot 25$ \\
\hline $4 \mathrm{BS}$ & 0.76 & 0.80 & 0.82 \\
\hline $4 B L$ & $1 \cdot 18$ & $1 \cdot 15$ & $1 \cdot 24$ \\
\hline $5 \mathrm{BS}$ & 0.63 & 0.53 & 0.44 \\
\hline $5 \mathrm{BL}$ & $1 \cdot 25$ & $1 \cdot 22$ & $1 \cdot 22$ \\
\hline $6 \mathrm{BS}$ & 0.72 & 0.64 & 0.71 \\
\hline 6BL & 1.03 & 1.03 & 1.09 \\
\hline 7BS & 0.69 & 0.78 & 0.73 \\
\hline $7 \mathrm{BL}$ & 1.07 & 1.09 & $1 \cdot 16$ \\
\hline 1RS & 0.34 & $0 \cdot 32^{*}$ & $0 \cdot 27^{*}$ \\
\hline $1 \mathrm{RL}$ & 0.83 & 0.79 & 0.84 \\
\hline 3RS & $0.13^{*}$ & $0 \cdot 39^{*}$ & $0.53^{*}$ \\
\hline $3 R L$ & 0.75 & 0.79 & 0.79 \\
\hline 4RS & $0.48^{*}$ & 0.65 & $0.57 *$ \\
\hline $4 R L$ & 0.78 & 0.79 & 0.78 \\
\hline $5 \mathrm{RS}$ & 0.36 & 0.50 & 0.55 \\
\hline $5 \mathrm{RL}$ & 0.85 & 0.93 & 0.95 \\
\hline $6 \mathrm{RS}$ & $0 \cdot 19^{*}$ & $0 \cdot 17^{*}$ & $0.25^{*}$ \\
\hline $6 \mathrm{RL}$ & 0.69 & 0.92 & 0.95 \\
\hline 7RS & $0 \cdot 26^{*}$ & $0 \cdot 25^{*}$ & $0 \cdot 26^{*}$ \\
\hline 7RL & 0.96 & 0.85 & 0.87 \\
\hline A-bivalents & $1 \cdot 87$ & $1 \cdot 91$ & 1.99 \\
\hline B-bivalents & $1 \cdot 85$ & $1 \cdot 85$ & 1.93 \\
\hline R-bivalents & $1 \cdot 12$ & $1 \cdot 21$ & $1 \cdot 21$ \\
\hline No. Plants & 7 & 17 & 22 \\
\hline No. Cells & 688 & 1100 & 1150 \\
\hline
\end{tabular}

derived. Moreover, the composition depends on the meiotic behaviour and chromosome transmission within $\mathrm{F} 1$ gametes. The meiotic behaviour of F1 hybrids with a genome formula AABBDR have been previously investigated (Tarkowski, 1969; Sánchez-Monge and Sánchez-Monge, 1977; Bernard and Bernard, 1978; Soler et al., 1980; Schlegel et al., 1980; Jouve et al., 1982, 1985). Cells with 7 A-genome bivalents 7 B-genome bivalents +7 D-genome univalents +7 R-genome univalents were recorded as the most frequent chromosome association in these hybrids. This meiotic behaviour corresponds well to that expected on the assumption of homologous pairing only, and opens the possibility of elimination or reciprocal substitution of some $R$ or $D$ homoeologous chromosomes in the F 2 and following generations. Our results on the chromosome composition of plants in F3 to F6 seem to confirm the assumption of $D / R$ substitutions. This is clear in the plants with $2 n=42$ chromosomes ( 29 out of 48 plants studies).

The substitution of chromosome $2 \mathrm{R}$ by $2 \mathrm{D}$ into hexaploid triticale has been found in a considerable number of secondary triticale lines (Zillinsky, 1973; Gustafson and Zillinsky, 1973, 1978; Merker, 1975; Gustafson and Bennett, 1976; Rogalska, 1978; Pilch, 1981a,b; Sandha et al., 1984; Armstrong and Fedak, 1985; Jouve et al., 1989). Most studies attribute this substitution to a series of desirable characteristics of segregant plants (Zillinsky, 1980; Lukaszewski and Gustafson, 1984; Varughese et al., 1986).

The variation in the level of meiotic pairing observed amongst different plants could be dependent upon some of the following causes: (i) genotype of each plant; (ii) chromosome constitution of the third genome of each plant; (iii) heterochromatin constitution of rye chromosomes of each plant. Firstly, the homozygosity or heterozygosity in the wheat genotype component, the only one coming from two different sources, could have a minor importance. Jung and Lelley $(1985 a, b)$ and Jung et al. (1985) studied the cytological and morphological expression of interactions between wheat and rye genomes in hexaploid triticale lines, that were developed using genetically pure lines of both parental species. They demonstrated that interactions between the rye and wheat genomes in triticale, rather than their genotypic constitution are responsible for the reduction in chiasma number in hybrids heterozygous for the wheat, rye or both components, In a previous study, we used C-banding in meiosis as an approach to the analysis of wheat and rye genome interactions in triticale, and observed that pairing intensity in this amphiploid is more dependent upon the intergenomic interaction between the rye and wheat genomes than upon their genotypic composition (Galindo and Jouve, 1989).

Secondly, the variation in the level of meiotic pairing observed amongst the different plants could be more influenced by the chromosome constitution of the third genome than for their 
Table 3 Mean number of chiasmata per chromosome arm in homozygous normal $(++)$, heterozygous (+ -) and homozygous deficient $(--)$ plants. $t$-tests concern the comparison of mean number of chiasmata per homologous arm among the three groups of plants. ${ }^{*}=$ Significant at the level of 5 per cent. ${ }^{* *}=$ Significant at the level of 1 per cent

\begin{tabular}{|c|c|c|c|c|c|c|}
\hline \multirow{2}{*}{$\begin{array}{l}\text { Chromosome } \\
\text { arm }\end{array}$} & \multicolumn{3}{|c|}{$\begin{array}{l}\text { Mean number of chiasmata } \\
\text { in plants with }\end{array}$} & \multicolumn{3}{|l|}{$t$ test } \\
\hline & $3 \mathrm{R}^{--}$ & $3 \mathrm{R}^{++}$ & $3 \mathrm{R}^{+-}$ & $3 \mathrm{R}^{--} \equiv 3 \mathrm{R}^{++}$ & $3 \mathbf{R}^{--} \equiv 3 \mathbf{R}^{+-}$ & $3 \mathrm{R}^{++} \equiv 3 \mathrm{R}^{+-}$ \\
\hline $2 \mathrm{AS}$ & 0.84 & 0.81 & 0.77 & 0.385 & 0.644 & 0.373 \\
\hline $2 \mathrm{AL}$ & $1 \cdot 31$ & $1 \cdot 23$ & $1 \cdot 21$ & 0.743 & 0.807 & 0.155 \\
\hline 4AS & 0.80 & 0.60 & 0.50 & $1 \cdot 294$ & $1 \cdot 322$ & 0.357 \\
\hline $4 \mathrm{AL}$ & $1 \cdot 17$ & $1 \cdot 06$ & 0.99 & 0.915 & $1 \cdot 242$ & 0.462 \\
\hline $5 \mathrm{AS}$ & 0.77 & 0.73 & 0.63 & 0.353 & $1 \cdot 226$ & 0.704 \\
\hline $5 \mathrm{AL}$ & $1 \cdot 21$ & $1 \cdot 19$ & $1 \cdot 13$ & 0.262 & 0.872 & 0.681 \\
\hline $6 \mathrm{AS}$ & 0.83 & 0.81 & 0.81 & 0.152 & 0.127 & 0.002 \\
\hline $6 \mathrm{AL}$ & $1 \cdot 17$ & $1 \cdot 16$ & 0.95 & 0.007 & 1.055 & 1.086 \\
\hline $7 \mathrm{AS}$ & 1.07 & $1 \cdot 01$ & 0.96 & 0.770 & 1.092 & 0.450 \\
\hline $7 \mathrm{AL}$ & 1.08 & $1 \cdot 13$ & $1 \cdot 12$ & 0.337 & 0.302 & 0.007 \\
\hline $1 \mathrm{BS}$ & 0.72 & 0.67 & 0.61 & 0.415 & 0.619 & $0 \cdot 304$ \\
\hline $1 \mathrm{BL}$ & $1 \cdot 15$ & 1.01 & $1 \cdot 13$ & 0.287 & 0.179 & 0.649 \\
\hline 2BS & 1.04 & 1.01 & 0.93 & 0.408 & 0.844 & 0.522 \\
\hline $2 \mathrm{BL}$ & $1 \cdot 13$ & 1.07 & $1 \cdot 15$ & 0.501 & $1 \cdot 345$ & 0.555 \\
\hline $3 \mathrm{BS}$ & 0.89 & 0.85 & 0.75 & 0.617 & 0.780 & 0.520 \\
\hline $3 \mathrm{BL}$ & $1 \cdot 23$ & $1 \cdot 19$ & $1 \cdot 15$ & 0.369 & 0.542 & $0 \cdot 212$ \\
\hline 4BS & 0.85 & 0.79 & 0.87 & 0.529 & 0.193 & 1.032 \\
\hline $4 \mathrm{BL}$ & $1 \cdot 24$ & $1 \cdot 20$ & $1 \cdot 15$ & 0.314 & 0.859 & 0.483 \\
\hline $5 \mathrm{BS}$ & 0.49 & 0.48 & 0.54 & 0.004 & $0 \cdot 298$ & 0.220 \\
\hline $5 \mathrm{BL}$ & $1 \cdot 25$ & $1 \cdot 17$ & $1 \cdot 23$ & 0.562 & 0.174 & 0.291 \\
\hline $6 \mathrm{BS}$ & 0.77 & 0.72 & 0.61 & 0.319 & 0.733 & 0.475 \\
\hline $6 \mathrm{BL}$ & 1.08 & 1.08 & $1 \cdot 04$ & 0.000 & 0.363 & 0.318 \\
\hline $7 \mathrm{BS}$ & 0.83 & 0.71 & 0.72 & 0.813 & 0.783 & 0.055 \\
\hline $7 \mathrm{BL}$ & $1 \cdot 16$ & 1.02 & 1.08 & 0.499 & 0.922 & $0 \cdot 212$ \\
\hline $1 \mathrm{RS}$ & 0.34 & 0.31 & 0.32 & 0.147 & 0.121 & $0 \cdot 121$ \\
\hline $1 \mathrm{RL}$ & 0.88 & 0.82 & 0.84 & 0.492 & 0.296 & 0.149 \\
\hline 3RS & 0.58 & 0.58 & $0 \cdot 13$ & 0.056 & $3.402 * *$ & $2 \cdot 422^{*}$ \\
\hline $3 R L$ & 0.81 & 0.86 & $0 \cdot 70$ & 0.336 & 0.543 & 0.751 \\
\hline 4RS & 0.59 & 0.61 & 0.64 & $0 \cdot 103$ & 0.283 & 0.145 \\
\hline $4 \mathrm{RL}$ & 0.84 & 0.78 & 0.68 & 0.478 & 0.900 & 0.422 \\
\hline 5RS & 0.55 & 0.48 & 0.52 & 0.462 & 0.187 & 0.252 \\
\hline $5 \mathrm{RL}$ & 0.95 & 0.93 & 0.93 & 0.249 & $0 \cdot 130$ & 0.000 \\
\hline 6RS & 0.29 & $0 \cdot 18$ & $0 \cdot 18$ & 0.847 & 0.705 & 0.000 \\
\hline $6 \mathrm{RL}$ & 0.95 & 0.94 & 0.92 & 0.144 & $0 \cdot 168$ & 0.235 \\
\hline 7RS & 0.30 & $0 \cdot 20$ & 0.32 & 0.690 & $0 \cdot 104$ & 0.582 \\
\hline $7 \mathrm{RL}$ & 0.90 & 0.88 & $0 \cdot 81$ & $0 \cdot 247$ & 0.866 & 0.639 \\
\hline No. plants & 7 & 7 & 6 & & & \\
\hline No. PMCs & 400 & 350 & 400 & & & \\
\hline
\end{tabular}

genotype. A negative and significant correlation between the $D / R$ ratio (number of chromosomes of D-genome/number of chromosomes of Rgenome) and the mean number of chiasmata in rye chromosomes was observed $(r=-0 \cdot 3785 ; t=$ $2 \cdot 4189 ; \mathrm{df}=44 ; 0.01<P<0.05)$. This result seems to imply that a positive interference between $D$ chromosomes and meiotic pairing of rye chromosomes exists. Rees (1955) and Rees and Thompson (1956) suggested that in rye, chiasma frequency and terminalization are polygenically controlled, and Lelley (1975a), Weimarck (1975), Jung and
Lelley $(1985 a, b)$ and Jung et al. (1985) demonstrated that the polygenic balance can break down when rye is placed in a wheat background. In conclusion, variations in the number of $\mathrm{D}$ chromosomes relative to $\mathrm{R}$ chromosomes present in the triticale background could affect with different intensity the meiotic stability of rye chromosomes. In hexaploid triticale (Thomas and Kaltsikes, 1974; Lelley, 1975b; Schlegel, 1978 $a$; Jung and Lelley, 1985a, $b$; Jung et al., 1985; Galindo and Jouve, 1989) and in wheat-rye addition lines (Schlegel, 1978b; Orellana et al., 1984), rye 
chromosomes always show reduced pairing at metaphase I, as an expression of their interaction with the wheat chromosomes. Recently, Fominaya and Orellana (1988) demonstrated a phenomenon of interference between wheat and rye chromosomes as a cause of the decrease of rye-rye and wheat-wheat homologous pairing observed at metaphase I in triticale with respect to their corresponding rye and wheat parents.

Finally, regarding the relationship between heterochromatin and chiasmata in both wheat and rye homomorphic bivalents it seems clear that chromosomes having C-bands in either the telomeres (rye) or pericentromeric regions (1B and $4 \mathrm{~B}$ in wheat) had the lowest mean number of chiasmata. Moreover, arms having subtelomeric or intercalary blocks of heterochromatin (4AL, 2BS and $5 \mathrm{BL}$ ) show increased levels of pairing relative to arms having similar or higher size. This agrees with the previous assumption of Dvorak and McGuire (1981) who suggested that differentiation at the level of pairing among genomes in $T$. aestivum could be related to the amount of DNA and heterochromatin present in chromosomes.

It was very interesting to note that chiasma number in chromosome arm $3 \mathrm{RS}$ in plants of constitution $3 \mathrm{R}+-$ was reduced by almost to a quarter in comparison with the equivalent homozygous condition, whether $3 \mathrm{R}++$ or $3 \mathrm{R}--$. Although allelic differences between plants $3 \mathrm{R}++, 3 \mathrm{R}+-$ and $3 \mathrm{R}-$ - cannot be excluded, there was not a significant different behaviour of the remaining arms, not even $3 R L$ (table 3 ), and these results led us to assume a local influence of the structure of C-heterochromatin on the pairing behaviour of each specific telomeric region. The present results on pairing behaviour of chromosome $3 \mathrm{R}$ suggest that the structural configuration of telomeric regions influences the pairing intensity, and this could be related with the interference between the DNA late replication of C-heterochromatin and cryptic structural requirements of the telomeric pairing initiation sites.

Previous studies of isogenic lines of triticale with or without telomeric heterochromatin in specific rye chromosome arms have indicated that the absence of C-heterochromatin increases chromosome paring (Thomas and Kaltsikes, 1976; Merker, 1976; Schlegel, 1982; Schlegel and Huelgenhof, 1985). However, analysis of the 3 RS chromosome arm in the present study suggests that there is no correlation between the presence or absence of C-heterochromatin and chromosome pairing in homozygous condition. This implies that heterochromatin content does not necessarily affect meiotic pairing as much as its distribution. As a consequence, it could be perhaps suggested that the removal of telomeric heterochromatin in specific rye chromosomes is not as important as their homozygous (deficient or normal) structure which is reached early in the amphiploid triticale. Our results support the view of Bennett (1974) who pointed out that heterochromatin plays a major role in meiotic pairing failure and cytological stability in triticale. We suggest that both the heterochromatin structure and the chromosome constitution play an important role in meiotic stability in secondary lines of triticale, and that in consequence both factors are to be into account in reducing meiotic instability in triticale.

Acknowledgements The authors thank Dr J. P. Gustafson for his assistance and criticism in revising the results. They also thank the Instituto Nacional de Investigaciones Agrarias of Spain for their financial support (project no 5784).

\section{REFERENCES}

ARMSTRONG, K. C. AND FEDAK, G. 1985. A reassessment of the number of rye chromosomes in hexaploid triticale cv. 'Welsh'( $\times$ Triticosecale Wittmack). Z. Pflanzenzüchtg., 94, 8-12.

BENNETT, M. D. 1974. Meiotic, gametophytic and early endosperm development in Triticale. In Triticale, Proc. Int. Symp., El Batan, Mexico, pp. 137-148.

BERNARD, M. AND BERNARD, S. 1978. Methods of gene transfer from bread wheat and rye to hexaploid triticale. In Sánchez-Monge, E. and García-Olmedo, F. (eds), Interspecific Hybridization in Plant Breeding, Proc. 8th Congress of Eucarpia, Madrid, Spain, pp. 181-189.

DVORAK, J. AND McGUIRE, P. E. 1981. Nonstructural chromosome differentiation among wheat cultivars, with special reference to differentiation of chromosomes in related species. Genetics, 97, 391-414.

FERRER, E., GONZALEZ, J. M. AND JOUVE, N. 1984. Identification of C-banding chromosomes in meiosis of common wheat, Triticum aestivum L. Theor. Appl. Genet., 67, 257-261.

FOMINAYA, A. AND OREllanA, J. 1988. Does differential $\mathrm{C}$-heterochromating content affect chromosome pairing in octoploid triticale? Heredity, 61, 167-173.

GALINDO, C. AND JOUVE, N. 1989. C-banding in meiosis: an approach to the study of wheat and rye genome interactions in Triticale. Genome (in press).

GUPTA, P. K. AND PRIYADARSHAN, P. M. 1982. Triticale: present status and future prospects. Advances in Genetics, 21, 256-341.

GUSTAFSON, J. P. AND ZILLINSKY, F, J. 1973. Identification of D-genome chromosomes from hexaploid wheat in a 42 chromosome triticale. Proc. 4th Int. Wheat Genet. Symp., Columbia, Missouri, pp. 225-232.

GUSTAFSON, J. P. AND ZILLINSKY, F. J. 1978. Influences of natural selection on the chromosome complement of hexaploid triticale. Proc. 5th Int. Wheat Genet. Symp., New Delhi, India, pp. 1201-1207. 
Gustafson, J. P. AND BennetT. M. D. 1976. Preferential selection for wheat-rye substitutions in 42-chromosome triticale. Crop Sci., 16, 688-693.

GUSTAFSON, J. P., LUKASZEWSKI, A. J. AND ROBERTSON, K. 1985. Chromosome substitutions and modifications in hexaploid triticale: a reevaluation. In Bernard, M. and Bernard, S. (eds) Genetics and Breeding of Triticale, Proc. 3rd Eucarpia Meeting on Triticale. Clermont-Ferrand, France, pp. 15-27.

JOUVE, N., DIEZ, N. AND RODRIGUEZ, M. 1980. C-banding in $6 \mathrm{X}$-triticale $\times$ Secale cereale $\mathrm{L}$. Hybrid cytogenetics. Theor. Appl. Genet., 57, 75-79.

JOUVE, N., MONTALVO, D. AND SOLER, C. 1982. C-banding in cytogenetics of $6 x$-triticale $\times$ Triticum aestivum L. hybrids. Z. Pflanzenzüchtg., 88, 311-321.

JOUVE, N., GONZALEZ, J. M., FOMINAYA, A. AND FERRER, E. 1985. The analysis of meiosis of the B genome of common wheat. Can. J. Genet. Cytol., 27, 17-22.

Jouve, N., GALiNDo, C., MESTA, M. DiAz, F. Albella, B., GARCIA, P. AND SOLER, C. 1989. Changes in triticale chromosome heterochromatin visualized by C-banding. Genome 32, 735-742.

JUNG, C. AND LELLEY, T. 1985a. Cytological and morphological expression of interactions between wheat and rye genomes in triticale. In Bernard, M. and Bernard, S. (eds), Genetics and Breeding of Triticale. Proc. 3rd Eucarpia Meeting on Triticale. Clermont-Ferrand, France, pp. 145-152.

JUNG, C. AND LELLEY, T. 1985b. Genetic interactions between wheat and rye genomes in triticale 2. Morphological and yield characters. Theor. Appl. Genet., 70, 427-432.

JUNG, C., LELLEY, T. AND ROBBELEN, G. 1985. Genetic interactions between wheat and rye genomes in triticale. 1 . Cytological results. Theor. Appl. Genet., 70, 422-426.

KALTSIKES, P. J., ROUPAKIAS, D. J. AND THOMAS, J. B. 1975. Endosperm abnormalities in Triticum-Secale combinations. I. $\times$ Triticosecale and its parental species. Can. J. Bot., 53, 2068-2076.

LELLEY, T. 1975a. Genetic control of pairing of rye chromosomes in triticale. Z. Pflanzenzüchtg., 75, 24-29.

LELLEY, T. 1975b. Identification of univalents and rod bivalents in triticale with Giemsa. Z. Pffanzenzüchtg., 75, 252-256.

LUKASZEWSKI, A. J. 1986. Mapping the D-genome from bread wheat for hexaploid triticale breeding. Proc. Int. Triticale Symp., Sydney, Australia, pp. 53-62.

LUKASZEWSKI, A. J. AND B. APOLINARSKA, B. 1981. The chromosome constitution of hexaploid winter triticale. Can. J. Genet. Cytol., 23, 281-285.

LUKASzews KI, A. J. AND Gustafson, J. P. 1984. The effect of rye chromosomes on heading date of triticale $\times$ wheat hybrids. Z. Pflanzenzüchtg., 93, 246-250.

LUKASZEWSKI, A. J. AND GUSTAFSON, J. P. 1988: Cytogenetics of triticale. In Janik, J, (ed.), Plant Breeding Reviews, vol. 5 , pp. 41-94.

MERKER, A. 1975. Chromosome composition of hexaploid triticale. Hereditas, 80, 41-52.

MERKER, A. 1976. The cytogenetic effect of heterochromatin in hexaploid triticale. Hereditas, 83, 215-222.

ORELlANA, J., CERMEÑo, M. C. AND LACADENA. J. R. 1984. Meiotic pairing in wheat-rye addition and substitution lines. Can. J. Genet. Cytol., 26, 25-33.

PILCH, J. 1981 a. Analysis of the rye chromosome constitution and amount of telomeric heterochromatin in widely and narrowly adapted hexaploid triticales. Theor. Appl. Genet., 60, 145-149.

PILCH, J. 1981b. Rye chromosome constitution and the amount of telomeric heterochromatin of the widely and narrowly adapted CIMMYT hexaploid triticales. Z. Pflanzenzüchtg., 87, 58-68.
REES, H. 1955. Genotypic control of chromosome behaviour in rye. I. Inbred lines. Heredity, 9, 93-116.

REES, H. AND THOMPSON, J. B. 1956. Genotypic control of chromosome behaviour in rye. II. Chiasma frequency in homozygotes and heterozygotes. Heredity, 10, 409-424.

ROGALSKA, S. 1978. Chromosome constitution of plants of selected lines of secondary hexaploid triticale. Hodowla Rosl. Aklim. Nasienn., 24, 357-364.

ROUPAKIAS, D. G. AND KALTSIKES, P. J. 1977. The effect of telomeric heterochromatin on chromosome pairing of hexaploid triticale. Can J. Genet. Cytol., 19, 543-648.

SANCHEZ-MONGE, E. AND SANCHEZ-MONGE, E. 1977. Meiotic pairing in wheat-triticale hybrids. Z. Pflanzenzüchtg., 79, 96-104.

SANDhA, G. S., GREVAL, K. D. AND SATIJA, C. K. 1984. Study of $\mathrm{R}-\mathrm{D}$ chromosome substitutions and their effect in triticale. Crop Improv., 11, 119-122.

SCHLEGEL, R. $1978 a$. Investigations on chromosomal pairing behaviour of hexaploid and octoploid triticale by Giemsa technique. Arch. Züchtungsforsch., 8, 1-11.

SCHLEGEL, R. $1978 \mathrm{~b}$. Pairing behaviour of chromosomes in wheat-rye addition lines. Genetics, 24, 1365-1375.

SCHLEGEL, R. 1982. Karyotype alterations and their effects on cytological and morphological features in hexaploid triticale. Proc. Romote Hybridization, Sofia, Bulgaria, pp. 14-15.

SCHLEGEL, R., ZARIPOVA, Z. AND SHCHAPOVA, A. J. 1980. Further evidence on wheat-rye chromosome pairing in $\mathrm{F} 1$ Triticale $\times$ wheat hybrids. Biol. Zbl., 99, 585-590.

SCHLEGEL, R. AND HUELGENHOF, E. 1985. Heterochromatin alterations in chromosomes of hexaploid triticale and their effects on meiotic pairing behaviour. Proc. 3 rd Eucarpia Meet. on Triticale. Clermont-Ferrand, France, INRA, pp. 35-47.

SOler, C., MONTAlvo, D. AND JOUve, N. 1980. Secondary association of univalent chromosomes in hybrids of hexaploid triticale and rye and wheat. J. Heredity, 71, 408-410.

SYBENGA, J. 1983. Rye chromosome nomenclature and homoeology relationships. Workshop Report. Z. Pflanzenzüchtg., 90, 297-304.

TARKOWSKI, C. 1969. Cytogenetics on hexaploid triticale hybrids with wheat and rye. Genet. Polonica, 1, 85-86.

THOMAS, J. B. AND KALTSIKES, P. J. 1974. A possible effect of heterochromatin on chromosome pairing. Proc. Natl Acad. Sci., USA, 71, 2787-2790.

THOMAS, J. B. AND KALTSIKES, P. J. 1976. The genomic origin of the unpaired chromosomes in triticale. Can. J. Genet. Cytol., 18, 687-700.

VARGHESE, J. P. AND LELLEY, T. 1983. Origin of nuclear aberrations and seed shrivelling in triticale: a re-evaluation of the role of C-heterochromatin. Theor. Appl. Genet., 66, 159-167.

VARUGHESE, G., SARI, E. E. AND ABDAlla, D. S. 1986. Two decades of triticale breeding and research at CIMMYT. Proc. Int. Triticale Symp., Sydney, Australia, pp. 148-169.

WEIMARCK, A. 1975. Cytogenetic behaviour in octoploid triticale. II. Meiosis with special reference to chiasma frequency and fertility in $\mathrm{F} 1$ and parents. Hereditas, 80 , 121-130.

ZIAUDDIN, A. AND KASHA, K. J. 1982. Giemsa C-band identification of rye chromosomes in some advanced lines of winter triticale. Can. J. Genet. Cytol., 24, 721-727.

ZILLINSKY, F. J. 1863. The triticale improvement program at CIMMYT. In Triticale, Proc. Int. Symp. El Batán, México, pp. 81-85.

ZILLINSKY, F. J. 1980. The influences of chromosome substitutions on some agronomic characteristics of hexaploid triticales. Hodowla Rosl. Aklim. Nasienn., 24, 383-388. 